\title{
Mengaburkan Batas dan Orientasi dalam Susunan Program Ruang di KBRI Singapura
}

\author{
Hera Monica dan I Gusti Ngurah Antaryama \\ Departemen Arsitektur, Fakultas Teknik Sipil dan Perencanaan, Institut Teknologi Sepuluh Nopember (ITS) \\ e-mail: antaryama001@gmail.com
}

\begin{abstract}
Abstrak -Desain pada bangunan kedutaan memberikan sebuah perhatian kepada beberapa aspek, salah satunya adalah aspek keamanan. Dari sudut pandang arsitektur, keamanan sering kali direpresentasikan dalam wujud pengolahan batas. Batas tersebut menjadikan desain kedutaan mempunyai karakter desain yang khas. Namun desain khas yang mengamankan tersebut seringkali memudahkan orang dalam mengenal pola susunan tempat (mudah ditebak hierarkinya). Hal ini membuat pengamanan kasat mata maupun tidak kasat mata, harus ekstra keras dalam menjalankan tugas mereka untuk mengamankan kedutaan. Salah satu cara merancang desain kedutaan yang tetap memenuhi aspek keamanan adalah menghadirkan susunan bentuk acak dalam mengaburkan orientasi. Hal ini juga sejalan dengan representasi sebuah kedutaan Indonesia yang terkesan ramah terhadap negara lain. Maka diusulkan sebuah rancangan kedutaan berkonsep Chaos, dengan menggunakan metode Surrealist Devices sebagai parameter dalam mengacak. Rancangan kedutaan yang berada di Singapura tersebut, menghasilkan tiga massa yang terlihat menyatu. Pola bentuk pada bangunan maupun lanskapnya ditata distorsi, yang diharapkan mampu mendistraksi orang yang berada di sekitar kedutaan tersebut.
\end{abstract}

Kata Kunci-Acak, Batas, Kedutaan, Chaos, Perilaku, Persepsi.

\section{PENDAHULUAN}

$\mathrm{L}$ ITERASI kedutaan berfungsi sebagai perwakilan suatu negara, yang bertujuan menjalin hubungan kerja sama dengan negara lain (Gambar 1 dan 2). Karena sebagai representasi dan mempunyai tingkat kedaulatan, maka kedutaan menaruh perhatian kepada beberapa aspek, salah satunya adalah aspek keamanan. Aspek keamanan tersebut berdampak pada desain bangunan kedutaan. Dari sudut pandang arsitektur, keamanan sering direpresentasikan dalam wujud pengolahan batas. Batas tersebut menjadikan desain kedutaan mempunyai karakter desain yang khas. Namun desain khas yang mengamankan tersebut seringkali memudahkan orang dalam mengenal pola susunan tempat (mudah ditebak hierarkinya). Hal ini membuat pengamanan kasat mata maupun tidak kasat mata, harus ekstra keras dalam menjalankan tugas mereka untuk mengamankan kedutaan.

Salah satu cara merancang desain kedutaan yang tetap memenuhi aspek keamanan adalah menghadirkan susunan bentuk acak dalam mengaburkan batas dan orientasi (Gambar 3). Hal ini juga sejalan dengan representasi sebuah kedutaan Indonesia yang menjadikan desain terkesan ramah terhadap negara lain [1]. Selain itu, susunan acak tersebut dapat juga mengubah image (citra) sebuah bangunan kedutaan, dimana dapat mempengaruhi persepsi manusia. Persepsi tersebut dapat berlanjut pada perilaku manusia, sehingga pendekatan perilaku diperlukan dalam perancangan.

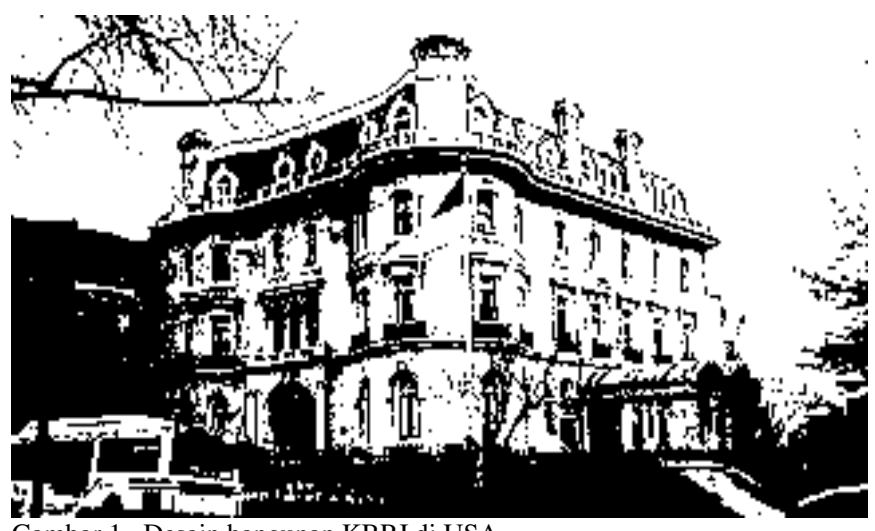

Gambar 1. Desain bangunan KBRI di USA.

Sumber : nomorcallcenter.com

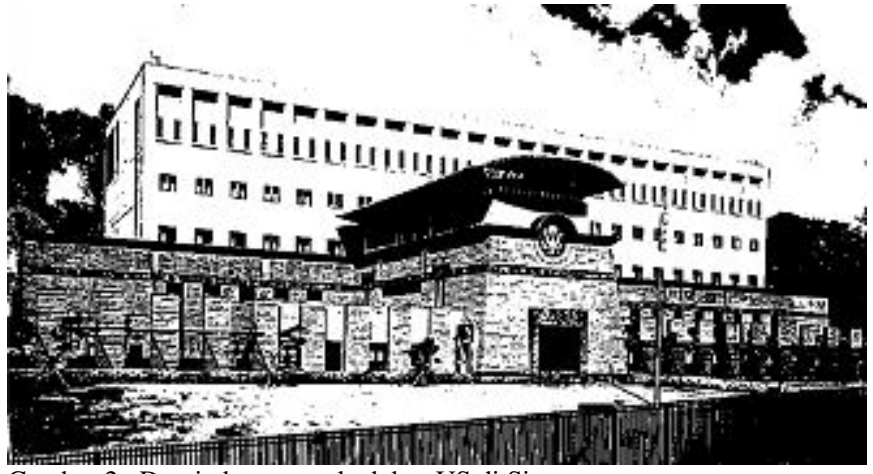

Gambar 2. Desain bangunan kedubes US di Singapura.

Sumber : travelwithhobbit.com

\section{METODA PERANCANGAN}

Arsitektur yang dihadirkan dalam objek rancang "KBRI di Singapura" yang terletak di Chatsworth Road Singapura ini, dirancang dalam pendekatan Perilaku, untuk mencapai kualitas yang diinginkan dalam mengubah persepsi akan batas. Kata perilaku menunjukkan manusia dalam aksinya, berkaitan dengan aktivitas manusia secara fisik, berupa interaksi manusia dengan sesama \& lingkungan fisiknya [2].

Diaplikasikan dengan metode Surrealist Devices, untuk menghidupkan kembali teknik penulisan otomatis sebagai situasi untuk membiarkan tangan yang membimbing, membebaskan imajinasi itu sendiri menghasilkan sebuah produk dengan proses kreatif bebas dari kendali tak sadar [3]. 


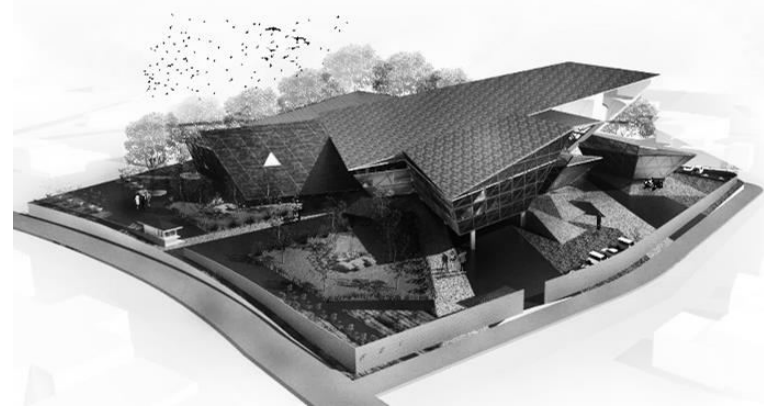

Gambar 3. Hasil akhir desain rancangan menggunakan Konsep Chaos.
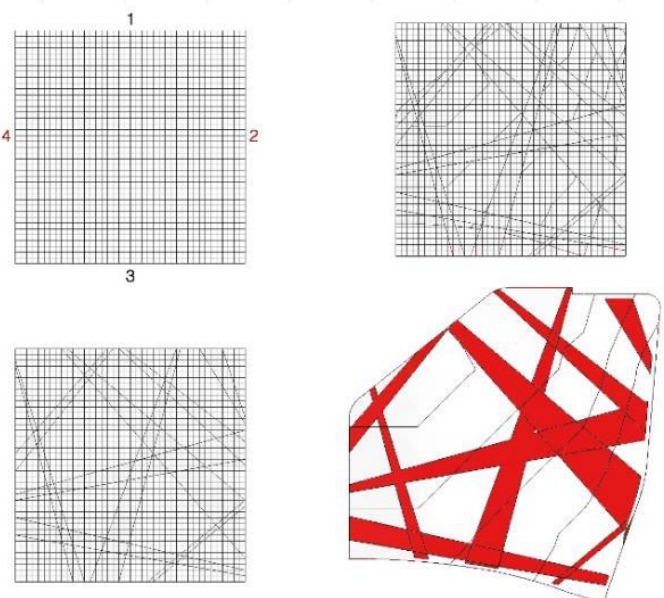

Gambar 4. Transformasi teknik acak pada lanskap.

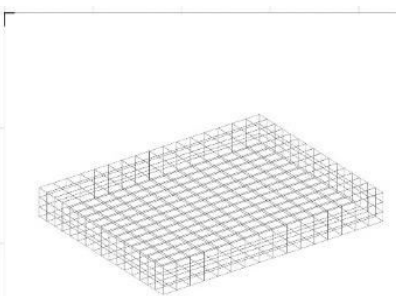

Pembuatan Grid dengan 3 dimensi

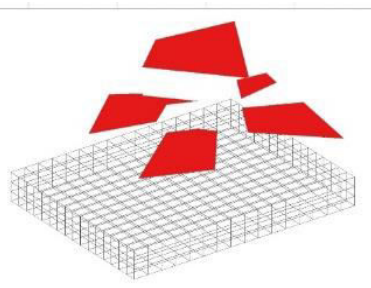

Penomoran acak menghasilkan zoning ruang dalam rupa bidang (2D)

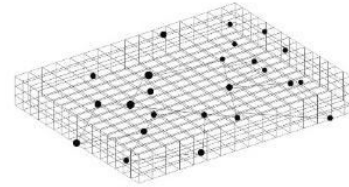

Penomoran acak dalam rupa 3D

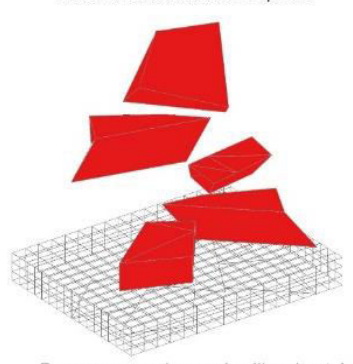

Penomoran acak menghasilkan bentuk bangunan

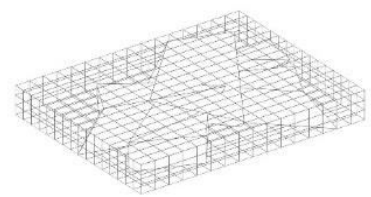

Menyambungakan titik dengan titik sehingga menghasilkan garis

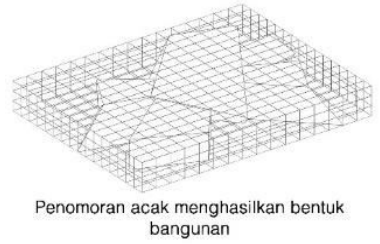

bangunan

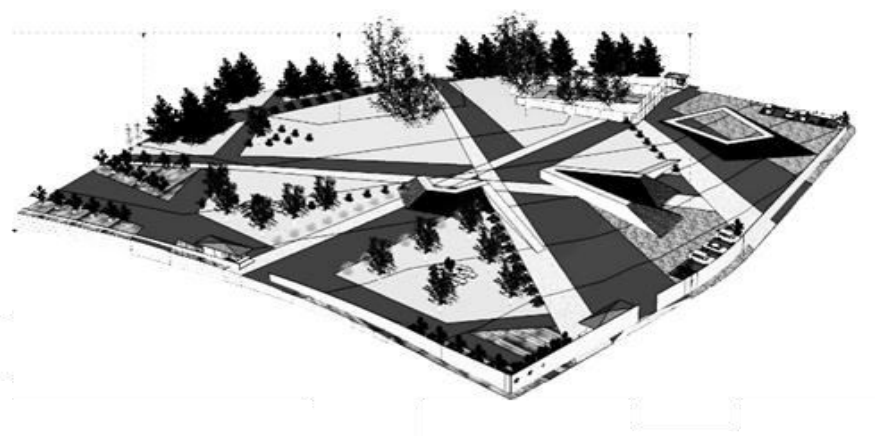

Gambar 6. Aplikasi teknik acak pada lanskap.

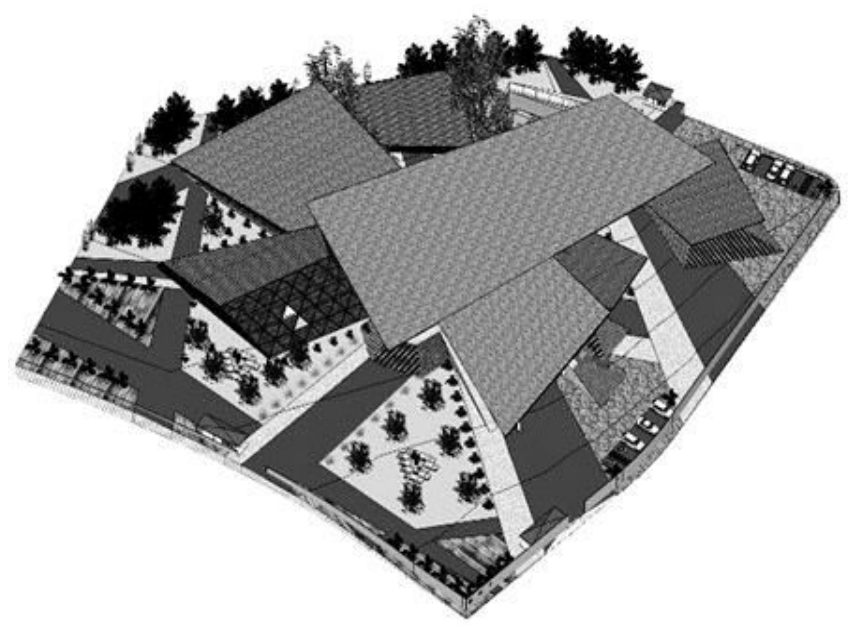

Gambar 7. Aplikasi teknik acak pada objek bangunan.

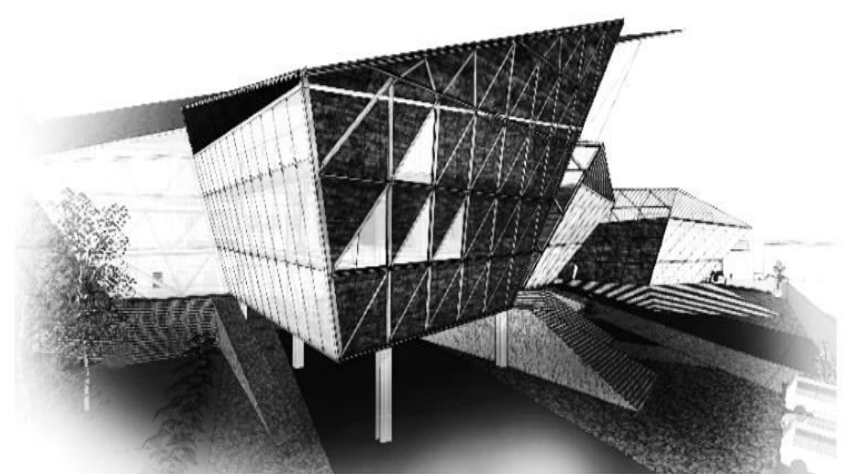

Gambar 8. Pemakaian kayu batik pada dinding bangunan (Aplikasi kriteria desain I ke konsep)

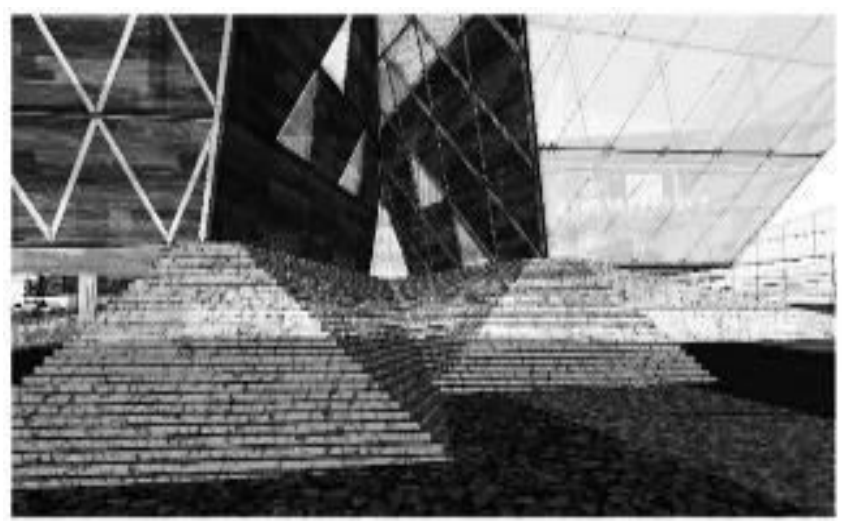

Gambar 9. Perbedaan lingkungan dari luar ke dalam bangunan (Aplikasi kriteria desain II ke konsep) 


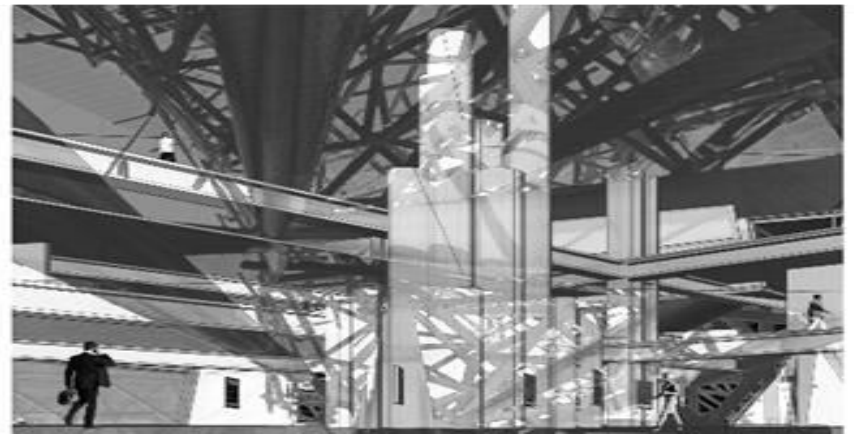

Gambar 10. Pemakaian material transparan dalam mengaburkan batas tegas (Aplikasi kriteria desain III ke konsep)

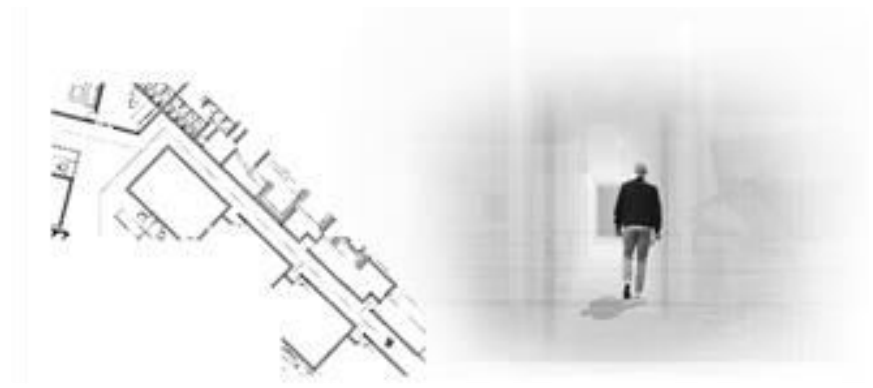

Gambar 11. Ruang yang mengarah ke zona terlarang dibuat membingungkan (Aplikasi kriteria desain IV ke konsep)

Teknik Acak merupakan teknik pemilihan yang memungkinkan tiap subjek dalam populasi mendapat kemungkinan sama untuk terpilih. Keuntungan teknik acak yaitu:

1) Menyeleksi bias dengan perbedaan sistematis peserta ketika diterima dan ditolak

2) Menghilangkan bias

3) Mengalihkan pandangan pengunjung dalam menerima

4) intervensi

5) Menghasilkan urutan tak terduga dari alokasi

6) Penyembunyikan pola alokasi (tidak terprediksi)

Teknik tersebut diaplikasikan dengan pengelompokkan berdasarkan jenis kegiatan. Lalu diberi nomor pada setiap kelompok dan diacak menggunakan tabel sehingga mendapatkan beberapa sampel. Setelah itu, hasil dari sampel tersebut disaring kembali dengan aturan-aturan batas pada sebuah bangunan kedutaan. Penerapan tersebut diaplikasikan pada perancangan lanskap (Gambar 4) dan bangunan objek (Gambar 5).

Dari parameter tersebut diharapkan menghasilkan sebuah rancangan yang dapat memicu chaos, yang didefinisikan sebagai unpredictability sistem gagasan kompleks dengan tujuan mengubah perilaku orang yang muncul secara acak, tidak terduga maupun tidak tertangkap, namun tetap mempunyai batasan aturan tertentu [4].

Chaos tersebut bisa jadi tidak direncanakan, karena merupakan sesuatu yang dapat berkembang, tidak terisolasi ruang dan waktu. Bentuk yang terdistorsi (non-geometri) dapat menyulitkan dalam menentukan wujud bentuk sebuah desain rancangan. Selain itu dapat membuat sebuah kesan dalam ekspresi komposisi yang diciptakannya. Karena itu,

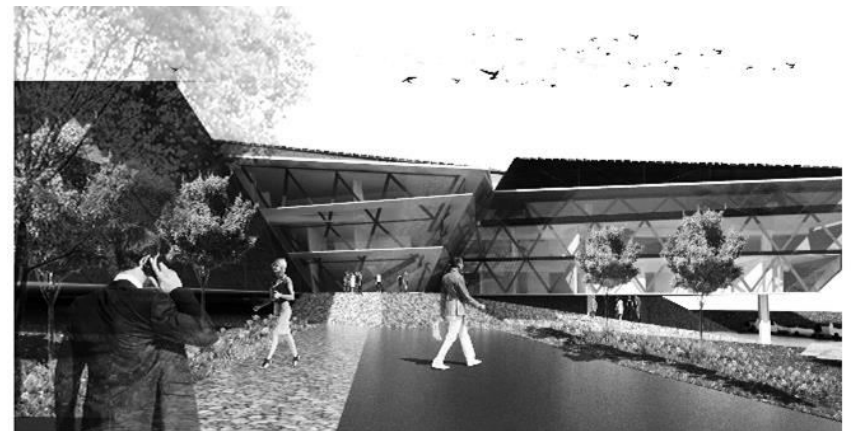

Gambar 12. Interior dengan sculpture yang chaos (Aplikasi kriteria desain V ke konsep)

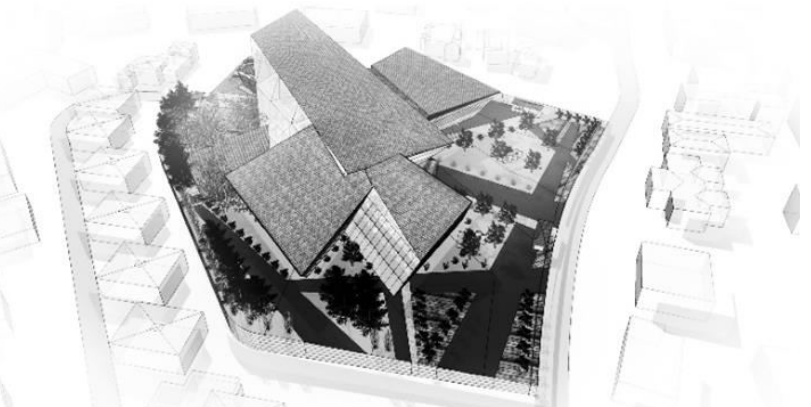

Gambar 13. Bentuk rancangan yang distorsi (Aplikasi kriteria desain VI ke konsep)

dampak dari wujud tersebut menghasilkan bangunan yang menonjol di antara lingkungannya.

\section{HASIL DAN EKSPLORASI}

Perhitungan teknik acak tersebut menghasilkan sebuah rancangan desain yang terbentuk dari penomoran grid. Dalam pembentukan bangunan tersebut, digunakan grid 2 dimensi yang diteruskan menjadi grid 3 dimensi. Grid tersebut dijadikan acuan dalam penomoran bentuk ruang serta struktur bangunan. Hal tersebut dilakukan untuk mempermudah penerapan bentuk rancangan, sehingga tidak adanya proporsi yang terjadi karena konsekuensi adanya teknik acak tersebut. Aplikasi dari pemilihan sampel teknik ini, mendapatkan wujud berupa lanskap (Gambar 6) dan bangunan (Gambar 7).

Penerapan konsep Chaos yang ditinjau dari Kriteria desain ini, menghasilkan sebuah eksplorasi perancangan akhir sebagai berikut:

1. Merepresentasikan Indonesa dengan memakai ekspresi Indonesia, namun tetap menciptakan suasana yang menimbulkan kesatuan toleransi antar negara (menghargai). Memakai material berbahan dasar kayu dengan corak batik yang merupakan salah satu ekspresi Indonesia. Kayu corak batik tersebut diaplikasikan pada dinding bangunan (Gambar 8).

2. Mengadakan sirkulasi atau bentuk yang kontras antara sesuatu yang jelas rasional dengan irasional. Kontras diterapkan pada bentuk bangunan, dimana terdapat massa yang dominan dan yang tidak dominan. Selain Itu, kontras juga diaplikasikan pada pintu masuk, dimulai dengan luar bangunan yang luas dan ramai (transportasi, manusia, dll), lalu masuk ke tempat 
sempit dan sunyi, menuju dalam bangunan yang cenderung ramai dan luas kembali (Gambar 9).

3. Menciptakan rancangan yang mempunyai kesan ramah "terbuka", namun tetap menjamin keamanan lingkungan sekitar terutama pengunjung turis maupun lokal. Mengaburkan batas yang tegas dengan pemakaian material transparan. Dalam rancangan ini, menggunakan material kaca (Gambar 10).

4. Membuat pengunjung tidak dapat mengetahui/menebak ruang-ruang maupun lokasi mereka sekarang berdiri (Unpredictability). Sirkulasi yang membingungkan ditujukan untuk pengunjung namun jelas untuk karyawan. Sehingga lokasi-lokasinya berada pada area tertentu. Seperti sirkulasi pengunjung yang mengarah ke zona terlarang, dibuat adanya permainan sirkulasi, seperti bercabang-cabang, sempit-lebar-sempit, atau letak entrance yang disembunyikan (Gambar 11). Selain itu, dibuat area-area yang mempunyai kemiripan (pengulangan) visual, sehingga membuat pengunjung mudah terdistraksi dan tidak dapat berorientasi akan susunan pola ruang.

5. Memberikan image chaos yang mampu mempengaruhi persepsi dan imajinasi seseorang. Menerapkan bagian yang kacau-balau dengan bentuk yang tidak dapat didefinisi, sehingga tiap orang akan berimajinasi sendiri dalam melihat image chaos tersebut (Gambar 12.

6. Menghadirkan batas yang terkaburkan.

7. Bentuk yang tidak presisi dan tidak mudah didefinisi (distorsi) wujud bentuknya (Gambar 13).

\section{KESIMPULAN}

Perancangan bangunan kedutaan ini merupakan bentuk implementasi dari konsep chaos dengan tujuan mengaburkan batas dan orientasi, dengan menggunakan pendekatan perilaku. Hasil dari perancangan ini di desain dalam bentuk distorsi yang memilikui 3 massa bangunan, namun saling menyatu satu sama lain. Bentuk distorsi tersebut memberikan eskpresi unpredictability dan visual yang tidak mudah ditebak. Hal ini membantu dan mempengaruhi tingkat keamanan yang menjadi aspek penting dalam fungsi kedutaan, selain itu hasil tersebut juga sejalan dengan representasi suatu negara yang terkesan ramah terhadap masyarakan sekitar. Dalam memudahkan penataan, parameter diambil dari metode Surrealist Devices, yang diharapkan menjawab kebutuhan masalah dan menjadi respon terbaik dalam usulan penyelesaian sebuah masalah desain kedutaan. Untuk pengembangan selanjutnya, diperlukan pengaplikasian berupa percobaan langsung.

\section{DAFTAR PUSTAKA}

[1] A. Syahmin, Hukum Diplomatik Dalam Kerangka Studi Analisis. Jakarta: Rajawali Pers, 2008.

[2] J. Laurens, Arsitektur Perilaku Manusia. Jakarta: Grasindo, 2014.

[3] K. Jormakka, Basics Design Methods. Birkhäuser, 2007.

[4] É. Cassar, The Case For Subtle Ar(t)chitecture. HYX, 2016. 